\title{
Hsien Wu, the founder of Chinese biochemistry and nutriology
}

\author{
Shu Zheng \\ Institute for the History of Natural Science, Chinese Academy of Sciences, Beijing 100190, China \\ $\bowtie$ Correspondence: zhengshu111@gmail.com
}

Hsien Wu (1893-1959) was a world-renowned biochemist and nutrition scientist with excellent achievements in protein chemistry, clinical chemistry, immunochemistry, nutriology and so on. He was also the founder of Chinese biochemistry and nutriology, and was regarded as "a giant of Chinese chemistry," and "without doubt the greatest chemist and perhaps the greatest scientist in China during the first half of the 20th century." Besides a productive scholar in pursuit of truth and perfection in career, his multiple interests, kindness and self-discipline also made him a patriot, a caring husband, a wise father, and a respected colleague.

Born in a scholarly family in Foochow, China, Hsien Wu once received the classical Chinese education and later took part in the civil service exam. In 1910, after 4 years of modern education in Fukien Provincial High School, he passed the government examination and won a Boxer indemnity scholarship to study abroad.

In 1911, Hsien Wu was sent to the United States, and entered the Massachusetts Institute of Technology. Dreaming of rebuilding Chinese navy, he first majored in naval architecture. But attracted by articles like Huxley's "On the Physical Basis of Life," he soon switched his major to chemistry and biology, and got his bachelor's degree in 1916. He then studied biochemistry with Professor Otto Folin at Harvard University, and obtained his doctor's degree in 1919.

His doctoral dissertation "A System of Blood Analysis" became a classic in the history of blood chemistry. It developed procedures to use only $10 \mathrm{~mL}$ blood samples to accomplish quantitative measurements of the major constituents of blood. Particularly, it's possible to measure the sugar content in blood or urine in a sample as small as one drop. In fact, scholars commented that without Wu's method, the discovery of insulin might have been hampered. These analytical procedures later were known as the "Folin-Wu" methods.

In 1920, Hsien Wu returned to China to work at the Peking

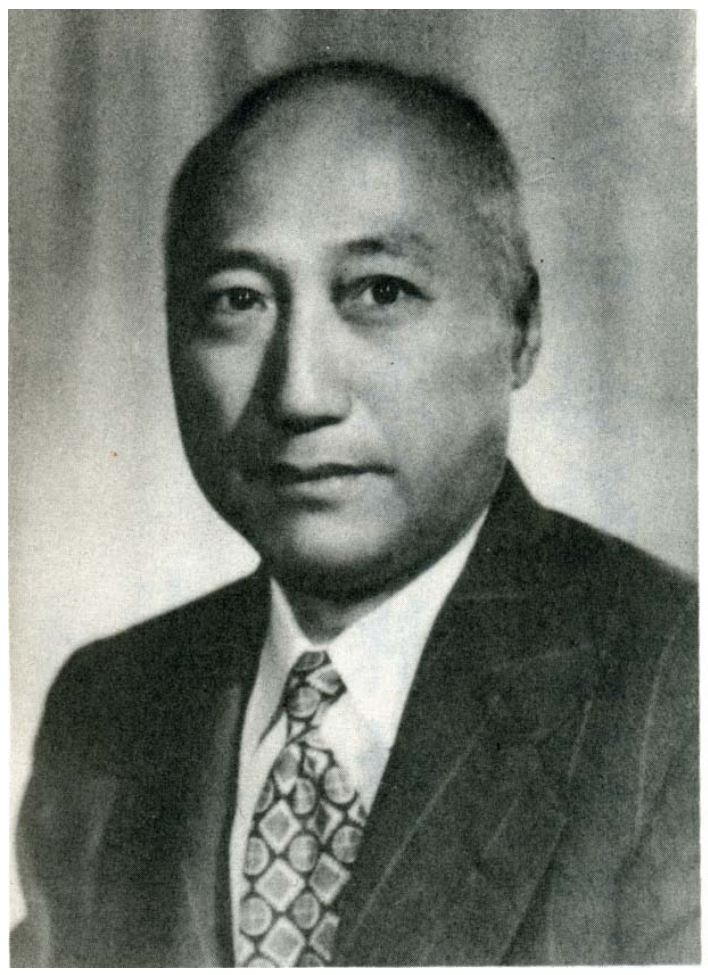

Figure 1. Hsien Wu.

Union Medical College (PUMC), a Rockefeller-endowed institution. From 1920 and on, he spent most of his time there, till the college was invaded by the Japanese army. During working at PUMC, he was appointed director of the department of biochemistry, the first Chinese director of a department there. This period was also regarded as the prime time of his scientific life. For instance, he led a large-scale research at that college-the study of protein denaturation. He and his colleagues published 16 essays about "studies on denaturation of proteins," along with other 14 related papers. In 1931, Hsien Wu published "Studies on Denaturation of 
Protein. XIII. A Theory of Denaturation," a landmark contribution to the international study of protein. Chemist Felix Haurowitz commented that Hsien Wu was the first to use labeled antigens for determining proteins in the presence of antibodies and the first to propose that the peptide chains in globular proteins are folded and unfold on denaturation.

Hsien Wu noticed the malnutrition states of many Chinese people at that time and determined to improve this situation through scientific research. At PUMC, Hsien Wu began to conduct his systematic study on the relationship between food and human health. He raised experimental animals with purely vegetarian diet and omnivorous diet respectively, and confirmed the benefit of omnivorous meal. Through the observation of protein regimens in rats, he further pointed out that the nature of the protein was critical. He published the first analysis of food composition in China, and conducted the first nutrition survey, as well as set up specific nutrition indices for all kinds of people. In addition, Wu was the director of the Nutrition Institute in Nanking during the 1940s.

Hsien Wu went to Columbia University as a visiting scholar in 1948 and failed to return to China because of war. He retired in 1953 after the break of coronary thrombosis. He settled down in Boston and died there in 1959.

As his son, excellent biologist Ray Wu, pointed out, Hsien Wu "lived the life of a true scientist." Scientific achievements of Hsien Wu are too many to be listed here. He wrote and published 163 scientific papers, as well as 3 books. He had membership in the American Society of Biological Chemists, and honorary membership in the Deutsche Akademie Naturforschor Leopoldina. He was on the advisory board of Biochemica et biophysica acta, and the Standing Advisory Committee on Nutrition of the Food and Agriculture Organization of the Untied Nations. Dr. D. D. Van Slykesaid once commented, "the brilliance of his mind and the beauty of his technique could be adequately appreciated only when one saw him in action. He was one of the great and truly original leaders in the creation of biochemistry today."

Professor Ray Wu also referred that elements of "classical Chinese gentleman (chun-tse) and philosopher" were combined in Hsien Wu's life. He was calm, never hurried, and self-disciplined. He told his children that good education was the best investment for them, and was much more important than material superiority. After Hsien Wu's death, his family decided not to leave money to their offspring, but to donate it to education and scientific research. All of Hsien Wu's children are experts in their own research areas.

Nevertheless, Hsien Wu was by no means a dull and cold person. He enjoyed warm family life, had a harmonious relationship with his wife all through his life. He was passionate

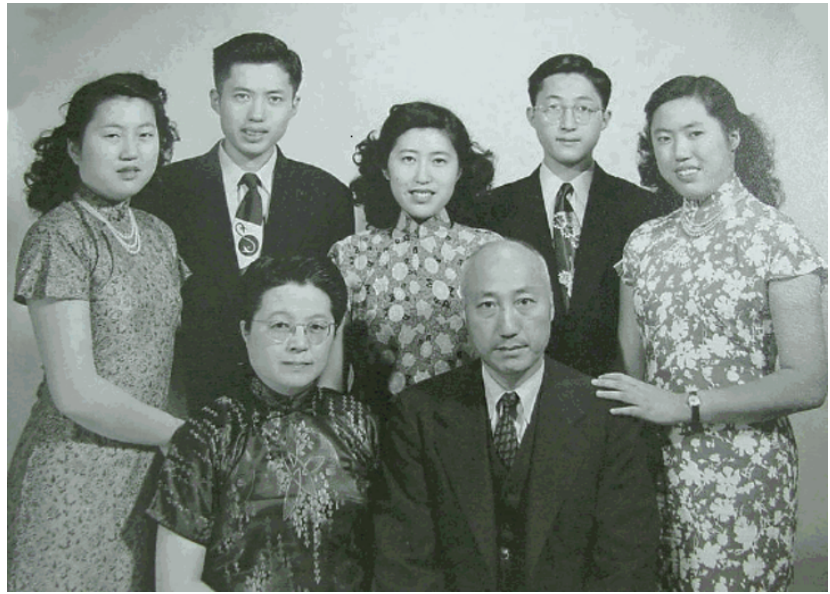

Figure 2. Hsien Wu and his family.

for the development of his motherland, willing to help with China's scientific development despite life-threatening situation. He cared about peace and welfare of humanbeing, and wrote "Guide on Scientific Life," in which he discussed the relationship between individuals and one's country. He imagined solving social problems with scientific method. His passion also resided in his multiple interests, such as all kinds of exercise, architecture, calligraphy, gardening, and so on. He was not only a great scientist, but a man with fully developed spirit and colorful life.

\section{REFERENCES}

Cao, Y. (1993). A biographical sketch of the father of biochemistry in China-in commemoration of the 100th birthday of Dr. Hsien Wu. Chin Historical Material Sci 14, 30-42. (曹育. 杰出的生物化学家 吴宪博士. 中国科技史料, 14(4): 30-42)

Bishop, C. (1982). Hsien Wu (1893-1959): A Biographical Sketch. Clinical chemistry. Vol. 28, No. 2. 378.

Wu, H. (1931). Studies on Denaturation of Protein. XIII. A Theory of Denaturation. Chin J Physicol 5, 321-344.

Reardon-Anderson, J. (1991). The Study of Change: Chemistry in China, 1840-1949. New York, USA: Cambridge University Press. 140-148.

Peking Union Medical College. (1993). In Memory of the 100th Anniversary of Professor Hsien Wu. Beijing: Beijing Medical University/Peking Union Medical College Press. (中国协和医科大学. 1993. 吴宪教授 100 周年纪念文集. 北京, 北京医科大学/中国协和 医科大学联合出版社.)

Wang, Y. (1991). Hsien Wu. The Biography of Chinese Modern Scientists 2. Beijing: Science Press. 453. (汪猷. 1991. 吴宪. 中国 现代科学家传记. 北京, 科学出版社. 453) 